\title{
AGREEMENT ON THE JOINT COMPREHENSIVE PLAN OF ACTION (JCPOA) BETWEEN IRAN AND THE UNITED STATES
}

\author{
Mohamad Amine El Khalfi \\ Morocco's Politician Observator \\ mohamad1995amine@gmail.com
}

\begin{abstract}
Joint Comprehensive Plan of Action (JCPOA) is the result of diplomatic negotiations reached by the United States, Britain, France, Russia, China, Germany and Iran in 2015 regarding the Iran Nuclear Agreement. The emergence of this agreement was due to Iran's actions abusing its nuclear development to serve as a weapon of mass destruction in 2011. In response to this, Western countries imposed economic sanctions on Iran in the hope of weakening Iran's position so that it does not have the ability to continue its nuclear weapons program. In fact, these sanctions succeeded in weakening the Iranian economy but were not politically effective enough because the Iranian government remained strong, this led to Iran being still involved in various conflicts in the region and still insisting on developing its uranium enrichment. Iran's tough stance made Western countries choose to bring Iran into the negotiations by making offers that could attract Iran's attention. During the Obama administration, the United States succeeded in bringing Iran into the negotiations. An achievement when the United States together with Britain, France, Russia, China, and Germany succeeded in getting Iran to agree to stop developing its nuclear weapons in exchange for the lifting of sanctions from the West. However, when the Donald Trump administration tensions began to reemerge with the assassination of one of Iran's war generals that took place in 2020. The United States succeeded in bringing Iran into the talks. An achievement when the United States together with Britain, France, Russia, China, and Germany succeeded in getting Iran to agree to stop developing its nuclear weapons in exchange for the lifting of sanctions from the West. However, when the Donald Trump administration tensions began to re-emerge with the assassination of one of Iran's war generals that took place in 2020. The United States succeeded in bringing Iran into the negotiations. An achievement when the United States together with Britain, France, Russia, China, and Germany succeeded in getting Iran to agree to stop developing its nuclear weapons in exchange for the lifting of sanctions from the West. However, when the Donald Trump administration tensions began to re-emerge with the assassination of one of Iran's war generals that took place in 2020.
\end{abstract}

Keywords: Agreement; International, JCPOA; Nuclear.

\section{A. INTRODUCTION}

The Iran nuclear deal is not fully supported by the United States' allies in the Middle East. Israel and Saudi Arabia, for example, have criticized and demanded the United States to make an agreement that does 
not only cover Iran's nuclear program but is broader to cover the ballistic missile program and Iran's role in conflictual relations in the Middle East region. Iran, which is considered a destabilizing force in the region, has led to the emergence of skepticism from countries allies of the United States in the region. They think it takes more than just a nuclear deal to stop Iran from wreaking havoc in the Middle East ${ }^{1}$.

The election of Donald Trump as the new leader of the United States brings new policies related to the Iran nuclear issue. On May 8, 2018, the United States officially withdrew from the nuclear deal and decided to reimpose sanctions on Iran. The United States' exit from the Iran nuclear deal was a one-sided decision that did not involve the other agreement signatories. The agreement is still seen by other countries as the best way to prevent Iran from becoming a nuclear power, although they admit that the agreement is not yet perfect (bbc.com, 2018). Despite the support of its allies in the Middle East, this controversial US policy has been opposed by many, including countries involved in the agreement. ${ }^{2}$

The United States' exit from the deal leaves the Iran nuclear deal in a vulnerable position. The remaining signatories are demanded to be able to protect Iran from the sanctions that the United States has re-imposed. On the other hand, Iran has increasingly emphasized its stance that the Iran nuclear deal is an agreement that can no longer be negotiated. Increasing tensions between Iran and the United States now have direct consequences for Iranian threats aimed at the United States and its closest allies in the Middle East, this condition further escalates the regional conflict. $^{3}$

This issue is important to research considering that the agreement that has been formed for most countries is the best way to gradually neutralize Iran's aggressive role in the Middle East. Iran is a country that holds an influential power in the Middle East and the United States is a country that has a strong power in international politics. The conflictual relationship between the two of them can have an effect on the escalation of conflict in the Middle East region. As a region with a very complex conflict, mistakes in decision making will drag many parties into the conflict.

Alexane Said once explained the evolution of international relations between Iran and the United States in the context of the Nuclear Agreement Framework. Saïd focuses on the United States point of view by applying realist, liberal, and strategic cultural theoretical concepts in their contestation of power, control and sovereignty. This research only uses the concept of the security dilemma in general in examining the changing patterns of relations between the United States and Iran, Saïd uses the

1 Wendt, A. Social Theory of International Politics, Cambridge University Press, Cambridge. 1999

2 Reuters 2018. Iran deal reached, Obama hails step towards more hopeful world, seen March 29, 2020,

3 The Atlantic 2015. Where the 2016 Candidates Stand on the Iran Nulclear Deal, viewed March 29, 2020, 
security dilemma that leads to the creation of the Iran nuclear deal and has not reached the case of the United States leaving the nuclear deal in 2018.

The purpose of writing this study is to analyze the factors that caused the United States to change its policy to exit the nuclear agreement through an analytic eclecticism approach using a combination of the security dilemma concept and cognitive consistency theory. The writing of this research will further provide an understanding of the factors that have contributed to the confrontational behavior of the United States and its allies in the Middle East towards Iran. As well as providing an understanding of the causes of changes in the United States' policy of choosing to exit the Iran nuclear deal ${ }^{4}$.

\section{B. RESEARCH METHODS}

The type of methodology used in this research is qualitative. This method was chosen to understand in depth the case of the confrontation between the United States and Iran in the nuclear agreement using data collection techniques in the form of literature studies. Literature study collects secondary data from books, journal articles, magazines, newspapers, and online articles using credible sources. The data analysis method used in this research is the data interpretation process. So after the data has been collected, the researcher needs to sort, categorize and interpret it so that it fits the research objectives.

\section{DISCUSSION}

\section{Dispute Contents of the Joint Comprehensive Plan of Action (JCPOA) Agreement}

Under the JCPOA agreement, Iran declares its willingness to destroy its reserves of moderately enriched uranium, reduce $98 \%$ of its reserves of low-grade enriched uranium, and reduce about 2/3 the number of gas rotators it has had over the past 13 years. ${ }^{5}$. In the 15 years following this agreement, Iran can only enrich uranium to $3.67 \%$. Iran is also willing not to build new heavy water reactors in the same period. Uranium enrichment activities are limited to only one facility that uses the first generation spinnerets in a 10 year period. Other facilities will be converted to avoid the risk of manufacturing nuclear weapons. To supervise and ensure that Iran complies with this agreement, the International Atomic Energy Agency (IAEA) can visit Iran's nuclear facilities periodically. In exchange, Iran receives aid from the United States and the European Union, and UN Security Council sanctions could also be reduced ${ }^{6}$.

But as leadership changed in the US, President Trump canceled US involvement in the deal in 2018. Trump's stance can actually be traced back to his campaign days when he declared that negotiators on

4 The Atlantic 2015. Where the 2016 Candidates Stand on the Iran Nulclear Deal, viewed March 29, 2020,

5 The Washington Post 2017. IAEA confirms Iran is meeting its commitments under nuclear agreement, viewed March 30, 2020,

6 The Atlantic, 2015 
the JCPOA deal were incompetent. ${ }^{7}$. According to Trump, the deal brings Iran closer to building its current nuclear weapons. However, this accusation was denied by a statement from The International Atomic Energy Agency (IAEA) which monitors Iran's nuclear program. The IAEA states that Iran is complying with all restrictions contained in the $\mathrm{JCPOA}^{8}$ (Washington Post, 2017). Even so, Trump still thinks that the JCOPA deal will not bring calm and peace ${ }^{9}$.

In the midst of all the debates regarding the US decision to leave the agreement, this paper sees that the perceived threat to Iran is one of the determinants of US exit from this nuclear deal. International anarchy in the constructivist perspective of Hobbesian makes Iran perceived as "the others" by the United States. This perception does not appear suddenly. If you look at its history, the relationship between the US and Iran is very dynamic. When the Shah's regime came to power, relations between the two countries were good. So that in 1967, Iran's nuclear development research program was supported by the US. However, after the Iranian revolution and regime change, the relationship between the two was considered conflictual. Relations deteriorated, especially after President Bush labeled Iran as the axis of evil. ${ }^{10}$.

It is this perception that President Trump is using again. In his speech President Trump explained how this perception was shaped after the regime's change in Iran in 1979 to an "extremist" regime. Since then, Iran's policies have been seen as a threat. According to President Trump, the deals that have been made with the relief of economic sanctions only benefit Iran. Trump even accused Iran of violating the deal ${ }^{11}$.

Another important factor behind Trump's decision is the US perception of Iran's regional activities. The Iranian regime has supported conflicts in the Middle East such as Syria and Yemen by sponsoring terror, supporting the Syrian dictator who uses missiles and weapons to attack civilians. Closing his speech, Trump also explained that the policy to exit the agreement must be done for the sake of US security ${ }^{12}$.

Criticism of many parties over the US exit from this deal did not shake the White House. President Trump even imposed additional economic sanctions on Iran (The White House, 2018). The JCPOA agreement at this time also cannot predict its sustainability even though countries such as France and China say they still want to show their commitment to this agreement. ${ }^{13}$.

\section{Indonesia's position in the Iran-United States nuclear deal}

7 Washington Post, 2017

8 CNN, 2018

9 Wilsonian Project 2016. A History of Iran's Nuclear Program, viewed March 29, 2019, I

10 Arms Control, 2002

11 PBS. How Iran Entered The Exist, viewed April 4, 2019,

12 Arms Control Association 2002. Bush Labels North Korea, Iran, Iraq an "Axis of Evil". BBC 2017. Iran nuclear deal: Trump's speech in full, viewed April 05, 2020,

13 Sputnik News 2019. France, China, Reaffirm Commitment to JCPOA, DPPRK Denuclearation, viewed April 8, 2020, 
The issue of Iranian nuclear is not something new for Indonesia. During the reign of President Susilo Bambang Yudhoyono, Indonesia was involved in the formation of UN Security Council Resolution 1747 which imposed tough sanctions on Iran regarding its nuclear development. However, this has drawn criticism at the domestic level. These criticisms prompted the DPR to propose its right of interpretation which was supported by most of its members at that time ${ }^{14}$. As a result of the emergence of these criticisms, at the next Iranian resolution, Indonesia declared abstention. Indonesia's abstention made Iran's Ambassador to the United Nations, Mohammad Khazee, directly expressed his appreciation for Indonesia and stated that the resolution would not prevent Iran from defending its rights, namely nuclear development with peaceful purposes. ${ }^{15}$.

Then what is the attitude of Indonesia regarding Iran's nuclear, in particular the JCPOA? In 2015, the official website of the Ministry of Foreign Affairs of the Republic of Indonesia stated that Indonesia welcomed the Iran nuclear deal as stated in the JCPOA regarding the peaceful use of nuclear. Furthermore, on this page Indonesia hopes that the agreement can help create a conducive situation in the Middle East and adopt Indonesian values that promote dialogue and diplomacy (Official Website of the Indonesian Ministry of Foreign Affairs) ${ }^{16}$. That is why Indonesia regrets the cancellation of the Iran nuclear agreement by the US unilaterally in 2018. Indonesian Foreign Minister, Retno Marsudi stated that Indonesia still hopes that the agreement will continue. The Vice President of Indonesia, Jusuf Kalla, also stated that the US policy made it difficult for Iran (Kompas, 2018). Such Indonesia's attitude cannot be separated from the values and norms adhered to by Indonesia, namely the peaceful use of nuclear through diplomacy and in the form of multilateralism, which has actually been pursued through the JCPOA.

\section{CONCLUSION}

The US withdrawal from the JCPOA is psychological due to the consistency of Trump's thinking that views the Iran nuclear deal as a bad and unreliable deal because under the nuclear deal, the US and its allies still feel a security dilemma which has prompted Trump to try to pressure Iran by leaving the nuclear deal. .

14 The White House 2018, Remarks by President Trump on the Joint Comprehensive Plan of Action,

15 The State Gov 2015, Joint Comprehensive Plan of Action, viewed March 29, 2020,

16 Indonesian Ministry of Foreign Affairs 2015, Indonesian Government Welcomes the Agreement on Iran Nuclear Program, Nasional.Kompas.Com 


\section{BIBLIOGRAPHY}

\section{Book :}

Wendt, A. 1999. Social Theory of International Politics, Cambridge University Press, Cambridge.

\section{Internet :}

Reuters 2018. Iran deal reached, Obama hails step towards more hopeful world, seen March 29, 2020,

(https://www.reuters.com/article/us-iran-nuclearidUSKCNOPMOCE20150714)

The Atlantic 2015. Where the 2016 Candidates Stand on the Iran Nulclear Deal, viewed March 29, 2020,

(https://www.theatlantic.com/politics/archive/2015/09/where-the-2016candidates-stand-on -the-iran-nuclear-deal / 448380 /).

The Washington Post 2017. IAEA confirms Iran is meeting its commitments under nuclear agreement, viewed March 30, 2020,

(https://www.washingtonpost.com/world/national-security/iaeaconfirms-iran-is-meeting-its- commitments-under-nuclear-deal / 2017/11/13 / 8d9b9fb0-c893-11e7-b0cf-7689a9f2d84e_story.html? utm_term $=.0$ cfe4ea72162).

Wilsonian Project 2016. A History of Iran's Nuclear Program, viewed March 29, 2019,

(https://www.washingtonpost.com/world/national-security/iaeaconfirms-iran-is-meeting-its-commitments-under- nuclear-deal / 2017/11/13 / 8d9b9fb0-c893-11e7-b0cf-7689a9f2d84e_story.html? utm_term $=.0$ cfe4ea72162).

PBS. How Iran Entered The Exist, viewed April 4, 2019, (https://www.pbs.org/wgbh/pages/frontline/shows/tehran/axis/map.ht $\mathrm{ml})$.

Arms Control Association 2002. Bush Labels North Korea, Iran, Iraq an "Axis of Evil".

BBC 2017. Iran nuclear deal: Trump's speech in full, viewed April 05, 2020, (https://www.bbc.com/news/world-us-canada-41617488).

Sputnik News 2019. France, China, Reaffirm Commitment to JCPOA, DPPRK Denuclearation, viewed April 8, 2020,

(https://sputniknews.com/europe/201903261073537753-france-chinajcpoa-north-korea/).

The State Gov 2015, Joint Comprehensive Plan of Action, viewed March 29, 2020, (https://www.state.gov/documents/organization/245317.pdf). 
The White House 2018, Remarks by President Trump on the Joint Comprehensive Plan of Action, (https://www.whitehouse.gov/briefingsstatements/remarks-president-trump-joint-comprehensive-plan-action/).

Indonesian Ministry of Foreign Affairs 2015, Indonesian Government Welcomes the Agreement on Iran Nuclear Program, Nasional.Kompas.Com 